\title{
EXAMINATION OF THE EFFECT OF NATIONAL AND AMATEUR DISABLED ATHLETES' DISABILTY TYPES ON SPORTS PARTICIPATION MOTIVATION
}

\author{
Oktay K1zarii, \\ Gönül Tekkurşun Demir², \\ Harun Genç ${ }^{3}$ \\ ${ }^{1}$ Bingöl Üniversitesi, \\ Beden Eğitimi ve Spor Yüksekokulu, \\ Bingöl, Turkey \\ ${ }^{2}$ Gazi Üniversitesi Spor Bilimleri Fakültesi, \\ Ankara, Turkey \\ 3Bingöl Üniversitesi, \\ Beden Eğitimi ve Spor Yüksekokulu, \\ Bingöl, Turkey
}

\begin{abstract}
:
In this study, the effect of motivation of participation in sports on various variables according to disability types of national athletes with disabilities and disabled amateur athletes has been examined. The sample of the study consisted of 159 male (127 amateurs, 32 national) who played sports in the sports clubs of the Physically Disabled Federation, the Hearing Impaired Federation, the Federation of the Visually Impaired Federation in the 2018-2019 season and played sports nationally $(\mathrm{N}=47)$ in the relevant federations and 60 female (45 amateurs, 15 nationals) disabled athletes. In the research, "Sports Participation Motivation Scale in Disabled Persons" (SPMSDP) developed by Tekkurşun, Demir, İlhan, Esentürk and Kan (2018) was used as a data collection tool. In the analysis of the data obtained in the research; frequency, arithmetic average, standard deviation; Pearson Moment Correlation Test, Mann-Whitney U and Kruskal-Wallis tests were used. According to the research result; internal motivation scores of nationally visually impaired athletes from the scores of visually impaired athletes engaged in amateur sports; internal motivation scores of national athletes with disabilities are the scores of athletes with visual impairments who do amateur sports; from the scores of the physically disabled athletes' intrinsic motivation scores, participation of visually impaired and hearing impaired athletes; Among the scores of the male motivated and visually impaired athletes, the average of the intrinsic motivation points of the male athletes with physical disabilities; the mean score of the athletes with low economic
\end{abstract}

i Correspondence: email okizar@bingol.edu.tr 
status, hearing, and physical disability athletes with a low average economic status; It was found that the score average of a motivational of the athletes with disabilities in primary school graduates was significantly higher than the average scores of athletes with high school and secondary school graduates.

Keywords: visually impaired, hearing impaired, disabled, sports, motivation

\section{Introduction}

Sportive activity has a vital place in the life of the disabled people. Sport is an important tool that increases the motivation of individuals and contributes to their social development. It is very important for all individuals in the society to devote time to sports to develop healthy lifestyle behavior (Tekkurşun et al., 2016). Some of the individuals who make up the society continue their lives with different deficiencies due to their developmental characteristics or later (Demir \& İlhan, 2019). There are a number of problems that citizens affected by disability face in meeting the requirements of normal life. These people form the most marginal segment of the communities in which they live, and their quality of life is lower compared to other individuals (Mittler, 2008). In order for disabled people to benefit more from sports activities and sports services, public institutions and local administrations should improve service efficiency and use resources effectively (K1zar et al., 2018). The importance of leisure activities for disabled people is undeniable.

For some, this only means passive relaxation, while for others it is elite physical activities (Janna, Monika, (2008). In order for a healthy society to be formed, people from all walks should be encouraged to do sports (Güven et al., 2000). Sport is one of the important supporters for the disabled (Demir, İlhan, Cicioğlu \& Kabak, 2017) in terms of being in a strong relationship with the society, not feeling isolated from the society, and being physically and psychologically good. This causes them to have a feeling of being left, which decreases their desire to learn or stop learning in athletes with disabilities (Deimann and Bastians, 2010, 1; Huett, Moller, Young, Bray, and Huett, 2008, 113; Jokelova, 2013, 189; Smith, 2008). Thus, if the athlete motivated positively then his/her performance and happiness level is expected to increase (Bozkurt, Demir \& Dursun, 2019). The Turkish term for motivation is defined as motivation or activating (Soyer, 2010). Motivation is a guiding force that moves the individual towards the goal he wants to achieve and activates to demonstrate purposeful behavior. This power, which enables the person to act to meet their needs, also positively affects emotional well-being after reaching the target (Tekkurşun Demir \& Cicioğlu, 2018). According to another definition, motivation is that people act according to their own wishes in order to reach the specified goal (Genç, 2004). The motive behind motivation, the concept of motivation, which is defined as the actuator, is a power that has three main features that activate, maintain the movement, and direct it in a positive direction (Eren, 2004). Individuals participate in different sports activities due to their internal and external motivation. It is found in 
individuals who participate in sports activities with their own free will without being externally impressive. It is stated that the individual is motivated internally if such people exercise for reasons such as self-development, personal satisfaction or pleasure. A person can participate in sports events due to external reasons such as reward, status, external environmental pressure. When this situation directs external factors rather than taking pleasure in the individual then the individual is motivated externally (Kazak, 2004). Motivation is one of the most important issues raised by psychology. Motivation lies in the basic structure of human behavior. While some motives are not easy to understand, others may be implicit and difficult to understand. No matter where they are and how they are done, a chain of motives or motives underlies each behavior (Cüceloğlu, 2006: 230). The process of motivation begins with the stage of recognizing a feature that the individual realizes he needs. It creates a tension when there is an inconsistency between the current situation and the expected situation. It was found that the greater the tension, the stronger the percentage of occurrence of behavior. Ultimately, the individual tends to behave to reduce tension. As a result of the behavior, the tension situation of the person who has saturated disappears (Funk, 2008: 17).

Teodosiuo (2005) says that the sum of sportsman and coach motivations determines motivation. Besides, exercise atmosphere is an important factor in the continuation of sports participation. Three characteristics need to be examined to analyze the participation of individuals in sports in any society. These are the beliefs, goals and motivation environment of the individual, and the behavior of the individual and the group. Among these three factors, we can say that motivation is a vital factor prerequisite for sports activities, and participation in sports is important in increasing the performance of disabled people. In this context, it was aimed to investigate the motivation levels of amateur and national athletes with disabilities in sports.

\section{Method}

\subsection{Research Model}

In this study, the screening pattern, one of the quantitative research models, was used. The pattern, which is generally used in studies and attempts to reveal the characteristics of a particular group, what the idea and cognitive, affective, and behavioral attitudes of a situation are, is called a survey pattern (Büyüköztürk, Çakmak, Akgün, Karadeniz, \& Demirel, 2012).

\subsection{Study Group}

In the 2018-2019 season, 159 male (127 amateurs, 32 nationalities), 60 female ( 45 amateurs, 15 national) handicapped athletes from the national athletes of the amateur athletes who do sports at clubs within the body of the Physically Disabled Federation, the Hearing Impaired Federation and the Visually Impaired Federation in the 2018-2019 season. In this context, 51 of the participants ( 39 men, 12 women) consist of visually-impaired, 88 (54 men, 34 women) hearing and 80 (66 male, 14 female) are hearing-impaired athletes. 


\subsection{Data Collecting Tool}

\subsubsection{Personal Information Form}

A demographic information form was created by the researchers to collect information about the participants' status of being amateur or national athletes, type of disability, gender, age.

\subsubsection{Sports Participation Motivation Scale in Disabled People}

It was developed by Tekkurşun, Demir, İlhan, Esentürk and Kan (2018). The scale consists of three sub-dimensions: Internal Motivation, External Motivation and Amotivational and 22 items in total. The items included in the Internal Motivation sub-dimension represent internal resources such as peace and happiness that athletes with disabilities feel when participating in sports. The intrinsic motivation sub-dimension consists of the first 12 items, does not contain reverse items and the calculated Cronbach Alpha coefficient is .93. The items in the External Motivation sub-dimension include the level of nutritional status of athletes with disabilities from external sources such as awards and popularity in participation in sports. This sub-dimension consists of 13 th, 14 th, 15th, 16th, 17th items, does not contain reverse materials and the calculated Cronbach Alpha coefficient is .78. The amotivational sub-dimension consists of items representing the athlete joining the sport without establishing a cause and effect relation without getting fed from internal or external sources. The calculated Cronbach Alpha coefficient of the non-motivation sub-dimension consisting of inverse items and the last 5 items in the scale is .88.

\subsection{Analysis of Data}

It was determined whether the data cover the prerequisites of the parametric tests before any analysis. In this context, normality test and homogeneity of variances were tested for variables. Accordingly, non-parametric tests were applied to the variables whose distribution was not in the range of -1 to +1 and the distribution was not normal (Büyüköztürk, Çakmak, Akgün, Karadeniz, \& Demirel, 2017). Arithmetic average (x), standard deviation (sd), minimum (min) and maximum (max) values were calculated to determine the sports participation motivation points of the athletes with disabilities who participated in the research. In addition, "Mann-Whitney U Test" and "Kruskal-Wallis Test" were used in the research. Accordingly, the " $Z$ " distribution statistics for the MannWhitney U Test and the "Chi-Square" distribution statistics for the Kruskal-Wallis Test were taken into consideration.

\section{Findings}

In this section, the findings obtained as a result of the analysis obtained from the participants are subjected to various statistical processes. 
Table 1. Distribution of Participants According to Gender,

Disability Type and Being National - Amateur Athlete

\begin{tabular}{llcccc}
\hline \multirow{2}{*}{ Gender } & $\begin{array}{l}\text { Being national-amateur } \\
\text { athlete status }\end{array}$ & $\begin{array}{c}\text { Visually } \\
\text { Impaired }\end{array}$ & $\begin{array}{c}\text { Hearing } \\
\text { Impaired }\end{array}$ & $\begin{array}{c}\text { Physically } \\
\text { Disabled }\end{array}$ & $\begin{array}{c}\text { General } \\
\text { Total }\end{array}$ \\
\hline \multirow{2}{*}{ Male } & Amateur Athlete & 31 & 41 & 55 & 127 \\
\cline { 2 - 6 } & National Athlete & 8 & 13 & 11 & 32 \\
\cline { 2 - 6 } & Total & 39 & 54 & 66 & 159 \\
\hline \multirow{2}{*}{ Female } & Amateur Athlete & 10 & 21 & 14 & 45 \\
\cline { 2 - 6 } & National Athlete & 2 & 13 & - & 15 \\
\cline { 2 - 6 } & Total & 12 & 34 & 14 & 60 \\
\hline
\end{tabular}

Table 1 shows the gender, disability type and the status of being an athlete for the disabled athletes. 159 male and 60 female athletes participated in the study. 39 of males are disabled, 54 of them are hearing, 66 of them are physically disabled. 12 of female are visually impaired, 34 of them are hearing, 14 are of them physically disabled. 127 of the male participants are amateur, 32 of them are national; 45 of female are amateur and 15 of them are national athletes. In this context, 172 of the participants are amateur and 47 of them are national athletes.

Table 2: Mann Whitney U Test Results According

to Disability Type of National and Amateur Athlete

\begin{tabular}{|c|c|c|c|c|c|c|c|c|}
\hline $\begin{array}{l}\text { Disability } \\
\text { Type }\end{array}$ & & & $\mathbf{N}$ & $\begin{array}{c}\text { Range } \\
\text { Average }\end{array}$ & $\begin{array}{c}\text { Range } \\
\text { Total }\end{array}$ & $\begin{array}{c}\text { Mann } \\
\text { Whitney } \\
\text { U }\end{array}$ & $\mathbf{Z}$ & $\mathbf{p}$ \\
\hline \multirow{6}{*}{$\begin{array}{l}\text { Visually } \\
\text { Impaired }\end{array}$} & \multirow{2}{*}{$\begin{array}{l}\text { Internal } \\
\text { Motivation }\end{array}$} & Amateur athlete & 41 & 23.73 & 973.00 & \multirow{2}{*}{112.000} & \multirow{2}{*}{-2.216} & \multirow{2}{*}{$.02^{*}$} \\
\hline & & National athlete & 10 & 35.30 & 353.00 & & & \\
\hline & \multirow{2}{*}{$\begin{array}{l}\text { External } \\
\text { Motivation }\end{array}$} & Amateur athlete & 41 & 27.40 & 1123.50 & \multirow{2}{*}{147.500} & \multirow{2}{*}{-1.370} & \multirow{2}{*}{.17} \\
\hline & & National athlete & 10 & 20.25 & 202.50 & & & \\
\hline & \multirow{2}{*}{ Amotivational } & Amateur athlete & 41 & 26.57 & 1089.50 & \multirow{2}{*}{181.500} & \multirow{2}{*}{-.579} & \multirow{2}{*}{.56} \\
\hline & & National athlete & 10 & 23.65 & 236.50 & & & \\
\hline \multirow{6}{*}{$\begin{array}{l}\text { Hearing } \\
\text { Impaired }\end{array}$} & \multirow{2}{*}{$\begin{array}{l}\text { Internal } \\
\text { Motivation }\end{array}$} & Amateur athlete & 62 & 46.95 & 2911.00 & \multirow{2}{*}{654.000} & \multirow{2}{*}{-1.395} & \multirow{2}{*}{.16} \\
\hline & & National athlete & 26 & 38.65 & 1005.00 & & & \\
\hline & \multirow{2}{*}{$\begin{array}{l}\text { External } \\
\text { Motivation }\end{array}$} & Amateur athlete & 62 & 44.02 & 2729.50 & \multirow{2}{*}{776.500} & \multirow{2}{*}{-.271} & \multirow{2}{*}{.78} \\
\hline & & National athlete & 26 & 45.63 & 1186.50 & & & \\
\hline & \multirow{2}{*}{ Amotivational } & Amateur athlete & 62 & 44.92 & 2785.00 & \multirow{2}{*}{780.000} & \multirow{2}{*}{-.249} & \multirow{2}{*}{.80} \\
\hline & & National athlete & 26 & 43.50 & 1131.00 & & & \\
\hline \multirow{6}{*}{$\begin{array}{l}\text { Physically } \\
\text { Disabled }\end{array}$} & \multirow{2}{*}{$\begin{array}{l}\text { Internal } \\
\text { Motivation }\end{array}$} & Amateur athlete & 69 & 36.28 & 2503.00 & \multirow{2}{*}{88.000} & \multirow{2}{*}{-4.158} & \multirow{2}{*}{$.00^{*}$} \\
\hline & & National athlete & 11 & 67.00 & 737.00 & & & \\
\hline & \multirow{2}{*}{$\begin{array}{l}\text { External } \\
\text { Motivation }\end{array}$} & Amateur athlete & 69 & 39.84 & 2749.00 & \multirow{2}{*}{334.000} & \multirow{2}{*}{-.641} & \multirow{2}{*}{.52} \\
\hline & & National athlete & 11 & 44.64 & 491.00 & & & \\
\hline & & Amateur athlete & 69 & 38.57 & 2661.50 & & & \\
\hline & Amotivational & National athlete & 11 & 52.59 & 578.50 & .500 & & \\
\hline
\end{tabular}
$\mathrm{p}<.05$ 
Table 2 shows the Man Whitney U test between SPMSDP according to the disability type of the athletes with disabilities and the status of being an amateur-national athlete. As a result of the analysis, a significant difference was found in the intrinsic motivation points of the athletes with visual and physical disabilities according to their amateur-national status. Accordingly, it was found that the intrinsic motivation scores of nationally impaired athletes ( $\mathrm{SO}$ national visually impaired $=35.30)$ were significantly higher than the scores of athletes with visual impairments $(\mathrm{SO}$ amateur visually impaired $=23.73)(\mathrm{Z}=-2.216$; $\mathrm{p}$ $=.00<.05)$. In addition, the internal motivation points of nationally handicapped athletes (SO national physically disabled $=67.00$ ) were found to be significantly higher than the scores of athletes with visual impairments $(\mathrm{SO}$ amateur physically disabled $=36.28)(\mathrm{Z}=-4.158 ; \mathrm{p}=$ $.00) .<, 05)$.

Table 3: SPMSDP Kruskal Wallis Test Result According to the Disability Type

\begin{tabular}{|c|c|c|c|c|c|c|}
\hline & Disability Type & $\mathbf{N}$ & $\begin{array}{c}\text { Range } \\
\text { Average }\end{array}$ & $\mathbf{x}^{2}$ & $\mathbf{p}$ & $\begin{array}{c}\text { Meaningful } \\
\text { difference }\end{array}$ \\
\hline \multirow{3}{*}{$\begin{array}{l}\text { Internal } \\
\text { Motivation }\end{array}$} & Visually Disabled (a) & 51 & 103.08 & \multirow{3}{*}{8.309} & \multirow{3}{*}{$.01^{*}$} & \multirow{3}{*}{$c^{*} a-b$} \\
\hline & Hearing Impaired (b) & 88 & 99.39 & & & \\
\hline & Physically Disabled (c) & 80 & 126.09 & & & \\
\hline \multirow{3}{*}{$\begin{array}{l}\text { External } \\
\text { Motivation }\end{array}$} & Visually Disabled (a) & 51 & 109.91 & \multirow{3}{*}{.636} & \multirow{3}{*}{.72} & \\
\hline & Hearing Impaired (b) & 88 & 106.32 & & & \\
\hline & Physically Disabled (c) & 80 & 114.10 & & & - \\
\hline \multirow[t]{3}{*}{ Amotivational } & Visually Disabled (a) & 51 & 101.00 & \multirow{3}{*}{1.481} & \multirow{3}{*}{.47} & \multirow{3}{*}{-} \\
\hline & Hearing Impaired (b) & 88 & 113.43 & & & \\
\hline & Physically Disabled (c) & 80 & 111.97 & & & \\
\hline
\end{tabular}

$\mathrm{p}<.05$

As can be seen in Table 3, the SPMSDP scores of the participant athletes according to the type of disability were examined with the Kruskal Wallis Test. Accordingly, there was a significant difference between participants' disability type and intrinsic motivation scores. The group in favor of score difference is marked with * symbol. As a result of the analysis, it was found that the intrinsic motivation scores of athletes with physical disabilities were significantly higher than those of the visually impaired and hearing impaired athletes (Chi-Square $=8.309 ; \mathrm{p}<.05$ ).

The Table 4 shows the Kruskal Wallis test, which is performed out among the subdimensions of the SPMSDP according to gender and disability types of athletes with disabilities. Accordingly, a significant difference was found in the internal motivation scores of male athletes according to disability types. The group in goodness of score difference is marked with * symbol. As a result of the analysis, it was determined that the average of internal motivation scores of male athletes with physical disabilities was significantly higher than the scores of male athletes with hearing disabilities and visually impaired people (Chi-square $=7.024 ; \mathrm{p}<.05)$. 
Oktay Kızar, Gönül Tekkurşun Demir, Harun Genç

EXAMINATION OF THE EFFECT OF NATIONAL AND AMATEUR DISABLED ATHLETES'

DISABILTY TYPES ON SPORTS PARTICIPATION MOTIVATION

Table 4: Kruskal Wallis Test Results According to Gender and Disability Type

\begin{tabular}{|c|c|c|c|c|c|c|c|}
\hline & & Disability Type & $\mathbf{N}$ & $\begin{array}{l}\text { Range } \\
\text { Average }\end{array}$ & $\mathbf{x}^{2}$ & $\mathbf{p}$ & $\begin{array}{c}\text { Meaningful } \\
\text { Difference }\end{array}$ \\
\hline \multirow{9}{*}{$\frac{0}{\sum^{\pi}}$} & \multirow{3}{*}{$\begin{array}{l}\text { Internal } \\
\text { Motivation }\end{array}$} & Visually Impaired (a) & 39 & 67.58 & \multirow{3}{*}{7.024} & \multirow{3}{*}{$.03^{*}$} & \multirow{3}{*}{$c^{*} b-a$} \\
\hline & & Hearing Impaired(b) & 54 & 75.75 & & & \\
\hline & & Physically Disabled (c) & 66 & 90.82 & & & \\
\hline & \multirow{3}{*}{$\begin{array}{l}\text { External } \\
\text { Motivation }\end{array}$} & Visually Impaired (a) & 39 & 79.62 & \multirow{3}{*}{.649} & \multirow{3}{*}{.72} & \multirow{3}{*}{-} \\
\hline & & Hearing Impaired(b) & 54 & 76.41 & & & \\
\hline & & Physically Disabled (c) & 66 & 83.17 & & & \\
\hline & \multirow{3}{*}{ Amotivational } & Visually Impaired (a) & 39 & 69.90 & \multirow{3}{*}{5.071} & \multirow{3}{*}{.08} & \multirow{3}{*}{-} \\
\hline & & Hearing Impaired(b) & 54 & 90.05 & & & \\
\hline & & Physically Disabled (c) & 66 & 77.75 & & & \\
\hline \multirow{9}{*}{ 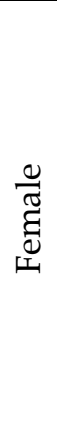 } & \multirow{3}{*}{$\begin{array}{l}\text { Internal } \\
\text { Motivation }\end{array}$} & Visually Impaired (a) & 12 & 37.46 & \multirow{3}{*}{4.063} & \multirow{3}{*}{.13} & \multirow{3}{*}{-} \\
\hline & & Hearing Impaired(b) & 34 & 26.68 & & & \\
\hline & & Physically Disabled (c) & 14 & 33.82 & & & \\
\hline & \multirow{3}{*}{$\begin{array}{l}\text { External } \\
\text { Motivation }\end{array}$} & Visually Impaired (a) & 12 & 32.00 & \multirow{3}{*}{.752} & \multirow{3}{*}{.68} & \multirow{3}{*}{-} \\
\hline & & Hearing Impaired(b) & 34 & 28.84 & & & \\
\hline & & Physically Disabled (c) & 14 & 33.25 & & & \\
\hline & \multirow{3}{*}{ Amotivational } & Visually Impaired (a) & 12 & 31.92 & \multirow{3}{*}{2.039} & \multirow{3}{*}{.36} & \multirow{3}{*}{-} \\
\hline & & Hearing Impaired(b) & 34 & 27.96 & & & \\
\hline & & Physically Disabled (c) & 14 & 35.46 & & & \\
\hline
\end{tabular}

$\mathrm{p}<.05$

Table 5: Economical Status' Kruskal Wallis Test Results

According to Disability Type and Minimum Wage

\begin{tabular}{|c|c|c|c|c|c|c|c|}
\hline $\begin{array}{l}\text { Disability } \\
\text { Type }\end{array}$ & & $\begin{array}{l}\text { Economical } \\
\text { Status }\end{array}$ & $\mathbf{N}$ & $\begin{array}{c}\text { Range } \\
\text { Average }\end{array}$ & $\mathrm{x} 2$ & p & $\begin{array}{l}\text { Meaningful } \\
\text { difference }\end{array}$ \\
\hline \multirow{9}{*}{$\begin{array}{l}\text { Visually } \\
\text { Impaired }\end{array}$} & \multirow{3}{*}{$\begin{array}{l}\text { Internal } \\
\text { Motivation }\end{array}$} & Low & 21 & 33.88 & \multirow{3}{*}{17,184} & \multirow{3}{*}{$.00^{*}$} & \multirow{3}{*}{$\begin{array}{c}\text { Low }{ }^{*} \text { Medium- } \\
\text { High }\end{array}$} \\
\hline & & Medium & 19 & 25.95 & & & \\
\hline & & High & 11 & 11.05 & & & \\
\hline & \multirow{3}{*}{$\begin{array}{l}\text { External } \\
\text { Motivation }\end{array}$} & Low & 21 & 24.76 & \multirow{3}{*}{ 743 } & \multirow{3}{*}{.69} & \multirow{3}{*}{-} \\
\hline & & Medium & 19 & 25.42 & & & \\
\hline & & High & 11 & 29.36 & & & \\
\hline & \multirow{3}{*}{ Amotivational } & Low & 21 & 28.12 & \multirow{3}{*}{1,883} & \multirow{3}{*}{.39} & \multirow{3}{*}{-} \\
\hline & & Medium & 19 & 26.61 & & & \\
\hline & & High & 11 & 20.91 & & & \\
\hline \multirow{9}{*}{$\begin{array}{l}\text { Hearing } \\
\text { Impaired }\end{array}$} & \multirow{3}{*}{$\begin{array}{l}\text { Internal } \\
\text { Motivation }\end{array}$} & Low & 45 & 52.74 & \multirow{3}{*}{9,998} & \multirow{3}{*}{$.00^{*}$} & \multirow{3}{*}{$\begin{array}{c}\text { Low }{ }^{*} \text { Medium- } \\
\text { High }\end{array}$} \\
\hline & & Medium & 31 & 39.45 & & & \\
\hline & & High & 12 & 34.54 & & & \\
\hline & \multirow{3}{*}{$\begin{array}{l}\text { External } \\
\text { Motivation }\end{array}$} & Low & 45 & 44.63 & \multirow{3}{*}{1,944} & \multirow{3}{*}{.37} & \multirow{3}{*}{ - } \\
\hline & & Medium & 31 & 47.73 & & & \\
\hline & & High & 12 & 35.67 & & & \\
\hline & \multirow{3}{*}{ Amotivational } & Low & 45 & 47.94 & \multirow{3}{*}{2,842} & \multirow{3}{*}{.24} & \multirow{3}{*}{-} \\
\hline & & Medium & 31 & 43.21 & & & \\
\hline & & High & 12 & 34.92 & & & \\
\hline \multirow{3}{*}{$\begin{array}{l}\text { Physically } \\
\text { Disabled }\end{array}$} & \multirow{3}{*}{$\begin{array}{l}\text { Internal } \\
\text { Motivation }\end{array}$} & Low & 49 & 47.89 & \multirow{3}{*}{14,388} & \multirow{3}{*}{$.00^{*}$} & \multirow{3}{*}{$\begin{array}{c}\text { Low }{ }^{*} \text { Medium- } \\
\text { High }\end{array}$} \\
\hline & & Medium & 21 & 31.74 & & & \\
\hline & & High & 10 & 22.70 & & & \\
\hline
\end{tabular}




\begin{tabular}{|c|c|c|c|c|c|c|}
\hline \multirow{3}{*}{$\begin{array}{l}\text { External } \\
\text { Motivation }\end{array}$} & Low & 49 & 42.05 & \multirow{3}{*}{4,148} & \multirow{3}{*}{.12} & \multirow{3}{*}{-} \\
\hline & Medium & 21 & 43.45 & & & \\
\hline & High & 10 & 26.70 & & & \\
\hline \multirow{3}{*}{ Amotivational } & Low & 49 & 43.13 & \multirow{3}{*}{2,759} & \multirow{3}{*}{.25} & \multirow{3}{*}{ - } \\
\hline & Medium & 21 & 39.12 & & & \\
\hline & High & 10 & 30.50 & & & \\
\hline
\end{tabular}

$\mathrm{p}<.05$

Table 5 shows the Kruskal Wallis test, which is performed between the athletes with disabilities and their economic status according to their disability types and minimum wages, and the sub-dimensions of SPMSDP. Accordingly, a significant difference was found in the intrinsic motivation points according to the economic status of the athletes with visual, hearing and physical disabilities. The group in favor of score difference is marked with * symbol. As a result of the analysis, it was determined that the average of internal motivation score of the athletes with low vision, hearing, and physically disabled athletes was significantly higher than the average score of athletes with medium and high economic status compared to the minimum wage $(\mathrm{p}<.05)$.

Table 6: Kruskal Wallis Test Results According to Education Level of Disabled Athletes

\begin{tabular}{|c|c|c|c|c|c|c|}
\hline & $\begin{array}{l}\text { Education } \\
\text { Level }\end{array}$ & $\mathbf{N}$ & $\begin{array}{c}\text { Range } \\
\text { Average }\end{array}$ & $\mathbf{x}^{2}$ & p & $\begin{array}{l}\text { Meaningful } \\
\text { Difference }\end{array}$ \\
\hline \multirow[t]{3}{*}{ Internal Motivation } & Primary (a) & 50 & 118,53 & \multirow{3}{*}{2,729} & \multirow{3}{*}{.25} & \multirow[t]{3}{*}{ 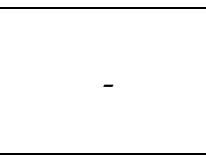 } \\
\hline & Secondary $(b)$ & 102 & 112,36 & & & \\
\hline & High School (c) & 67 & 100,04 & & & \\
\hline \multirow[t]{3}{*}{ External Motivation } & Primary (a) & 50 & 115,91 & \multirow{3}{*}{1,527} & \multirow{3}{*}{.46} & \multirow{3}{*}{-} \\
\hline & Secondary $(b)$ & 102 & 104,40 & & & \\
\hline & High School (c) & 67 & 114,12 & & & \\
\hline \multirow[t]{3}{*}{ Amotivational } & Primary (a) & 50 & 130,77 & \multirow{3}{*}{8,734} & \multirow{3}{*}{$.01^{*}$} & \multirow{3}{*}{$a^{*} c-b$} \\
\hline & Secondary (b) & 102 & 99,75 & & & \\
\hline & High School (c) & 67 & 110,10 & & & \\
\hline
\end{tabular}

$\mathrm{p}<.05$

According to the level of education of the disabled athletes participating in the research, the results, in which the average score of the SPMSDP were examined by the Kruskal Wallis test are given in Table 6. As a result of the analysis, a significant difference was found in the amotivational sub-dimension. The group in favor of score difference is marked with ${ }^{*}$ symbol. Accordingly, the average of non-motivation of the athletes with disabilities in primary school graduates is significantly higher than the average scores of athletes with high school and secondary school graduates (Chi-Square $=8.734 ; \mathrm{p}<.05)$.

\section{Discussion}

159 male and 60 female athletes participated in the study, which aims to determine motivation levels of amateur and national athletes with disabilities. 
In the first finding of the research, there was a significant difference found in the internal motivation scores of the visually impaired athletes according to their status as amateur athletes or national athletes. Accordingly, it was found that the internal motivation scores of the nationally impaired athletes were significantly higher than the scores of the visually impaired athletes who do sports as amateurs $(Z=-2.216 ; p=.00$ $<.05)$. Besides, the internal motivation scores of athletes with national disabilities were found to be significantly higher than those of the visually impaired athletes doing sports as amateurs $(Z=-4.158 ; p=.00<, 05)$. In the research of Bozkurt et al. (2019) It was found that the internal motivation of participating in the sport was significantly higher compared to non-national athletes. In the study of Demir and İlhan (2019), it was found that the external motivations of the athletes who were national were significantly higher in participation to sports than non-national athletes. In the study of Coşkuntürk (1988), he found that the level of motivation of the athletes who were national in their branch was higher than that of non-national athletes. In the study of Tekkurşun Demir and İlhan (2019), it was determined that the external motivation scores of those who are national athletes are significantly higher than non-national athletes. Frederic et al. (1996) found that elite athletes have high motivation for success in their studies. In the study of Aslan and Kuru (2002) say that, professional 1st, 2nd, 3rd league there is an increase in success patterns in parallel with the increase in the level of league, where league and amateur football players play motivations for success. In this study, it can be thought that selfconfidence is the most important among the national athletes with disabilities in terms of the difference in sports motivation level compared to amateur athletes with disabilities. In the study of Bozkurt et al. (2019), they found that the intrinsic motivation subdimension differs significantly according to the status of being a national athlete. In his study by Yildırım (2017), he suggested that the competition motivation of the athletes who struggle in different branches in the university teams also changed. In the study of Temel (2018), he found significant differences in motivation levels in athletes struggling in different branches such as wushu and table tennis. It is stated in the study conducted by Ayar (2017) that the form of the exercise revealed a differentiation in the motivation to participate in sports. It was resulted that the athletes engaged in individual sports in the sports category variable had a higher level of competition compared to athletes doing team sports (Yalçın et al. 2017). Team play is the key word in motivation. The motivation of the national athletes with disabilities can be opened with high motivation and high self-confidence. However, high motivation levels of national athletes with disabilities are thought to result from external reward differences.

In the second finding of the study, it was found that the internal motivation scores of athletes with physical disabilities were higher than those of the visually impaired and hearing impaired athletes (Chi-Square $=8.309 ; \mathrm{p}<.05$ ). When Bozkurt et al. (2019) analyzed according to the disability status of the participation in sports motivation scale, they found a significant difference between the internal and external motivation subdimensions, while they found a significant difference in the amotivational subdimension. When we compare the physically handicapped athletes with the hearing and 
visually impaired athletes, we can say that the sports have an important place in their lives. When Yalçın et al. (2017) examine the results between the sports category variable of athletes and the motivation to participate in sports; found that there was a statistically significant difference between individual athletes and team athletes in favor of individual athletes in the sub-dimension of the competition. Kurková et al. (2011) concluded that sports play a very important role in their lives for the hearing impaired. According to this result, they say that the frequency of participation in sports is an important impressive variable, both internally and externally.

A significant difference was determined between SPMSDP sub dimensions of gender and disability types of athletes with disabilities according to the types of disability in the internal motivation scores of male athletes. According to this, it was determined that the average of internal motivation scores of male athletes with physical disabilities were significantly higher than the scores of athletes with disabilities and hearingimpaired athletes (Chi-Square $=7.024 ; \mathrm{p}<.05$ ). In the study of Demir and Illhan (2019), the motivation levels of hearing-impaired female athletes were found to be significantly higher than that of men. In the study of Tekkurşun Demir and Illhan (2019), it was determined that the amotivational scores of female athletes with visual impairment differ significantly from males. Unlike the research findings, Bozkurt et al. (2019) did not find any significant difference between the gender of the disabled individuals and the mean scores obtained from the sub-dimensions of the sports participation motivation scale. In addition, Eroğlu (2007), Y1lmaz (2007) and Gülbahçe et al. (2018) reveal that there is a significant difference between gender and motivation in their studies. In different studies on the subject, it was found that gender was an important variable in motivation in participation in sports in a significant part (Demirezen et al., 2016; Aycan \& Y1ld1z, 2016; Kaman et al., 2017). In the study of Tekkurşun Demir and İlhan (2019), there was no significant difference in terms of gender variable in the motivation of sports participation motivation of visually impaired female and male athletes. We can say that it is the most important reason that women and men with disabilities do not share equal roles in sports branches at different disability levels and that they have different levels of motivation to participate in sports.

In the other finding of the research, it was determined that the average of internal motivation score of the athletes with low, low vision, hearing and physical impairment compared to the minimum wage was significantly higher than the average score of the athletes with medium and high economic status compared to the minimum wage. In the study of Turan (2010), concluded that the economic difficulties of the students' families affected both boys and girls' loneliness feelings and depression levels.

In the last finding of the study, there was a significant difference in the nonmotivation sub-dimension according to the education level of disabled athletes (ChiSquare $=8.734 ; \mathrm{p}<.05)$. It was found that the average of non-motivation of the athletes with disabilities in primary school graduates was significantly higher than the average scores of athletes with high school and secondary school graduates. Accordingly, as the level of education increases, the reasons for participation in sports become clear, and 
awareness of internal and external causes in participation in sports increases. In the study of Bozkurt et al. (2019), they found a positive correlation between sports year and amotivational at a level of $17.6 \%$, and a significant relationship between sports year, intrinsic motivation and extrinsic motivation. According to (Aygün, 2004) to move, exercise, participate in sports activities, regardless of the type of disability give pleasure to the individual. It is said that pleasure that has been experienced by this sportive activity increase the life motivation of the individual. In the study of Polat et al. (2018), as the frequency of participation in sports increased, there was a significant decrease in the level of amotivational. In the level of motivation, it is thought that as the education level progresses, the level of participation in sports will increase. For this reason, we can say that the ratio of people with disabilities in educational life should be increased in order to be able to communicate more with their peers in social life and thus to do sports. In this way, it is thought that the level of participation of individuals with disabilities in sports will increase more consciously. Karakaş et al. (2015) reached out the result that while the frequency of participation in sports increase, there are differences and increases in motivation level. In a different study, when we consider the level of education and the level of interest in sports in Malatya province, it is concluded that the interest in sports increases as the level of education increases (Karataş et al. 2011). Sports experts say that individuals with disabilities will be more extroverted, more social, more active, prioritizing more sense of belonging and successful in self-realization.

As a result, it was observed that the intrinsic motivation scores of the nationally impaired athletes were higher than the scores of the visually impaired athletes doing sports as amateurs. It was concluded that the intrinsic motivation scores of athletes with national disabilities were higher than those of the visually impaired athletes who were engaged in amateur sports. It was found that the intrinsic motivation scores of athletes with physical disabilities were higher than those of the visually impaired and hearingimpaired athletes. It was determined that the average of intrinsic motivation score of physically handicapped male athletes was higher than that of the hearing impaired and visually impaired male athletes. It was found that the average of intrinsic motivation scores of the low-visual, hearing and physically disabled athletes with low economic status was higher than the average of the athletes with medium and high economic status. It was concluded that the average of amotivational of athletes with disabilities in primary school graduates is significantly higher than the average scores of athletes with high school and secondary school graduates. In terms of internal motivation tendency factors, the motivation to make own-self happy is an important factor, while in the external motivation, it is thought that achieving status and being successful is an important factor. It is thought that the level of motivation significantly increases the desire to play sports and participate in sports activities in individuals with disabilities. Therefore, it is recommended to pay attention to motivational factors for the participation of disabled children and individuals in sports activities. In addition, it is recommended to evaluate the performance by applying SPMSDP scale to athletes with disabilities, and then apply the athletes to a motivational-enhancing program in a certain period, and to apply 
performance and SPMSDP again. Hence, revealing the relationship between motivation and performance can have significant and striking results.

\section{Conflict of Interest Statement}

The authors declare no conflicts of interests.

\section{About the Authors}

Associate Professor Oktay K1zar, Bingöl Üniversitesi, Beden Eğitimi ve Spor Yüksekokulu, Bingol, Turkey. Research interests: disabled individuals, motivation, training science, sports psychology.

Gönül Tekkurşun Demir, Gazi Üniversitesi, Sports Science Faculty, Bingol, Turkey. Research interests: disabled individuals, motivation, sports psychology.

Research Assistant, Associate Professor Harun Genç, Bingöl Üniversitesi, Beden Eğitimi ve Spor Yüksekokulu, Bingol, Turkey. Research interests: disabled individuals, motivation, training science, sports psychology.

\section{References}

Aslan, A., Kuru, E. (2002). Differences of Success Motivation of Professional and Amateur Players and Their Relationship with Sports Experience, Journal of Gazi Physical Education and Sports Sciences, VII (2002), 2 : 23 - 30.

Ayar, H. (2017). Investigation of Motivation Factors Effective in Participation for Recreational Exercise for Fitness and Crossfit Centers, Master Thesis, Trakya University, Institute of Social Sciences, Department of Recreation Management, Edirne.

Aycan, A., ve Yıld1z, K. (2016). Investigation of Sports Participation Motivations of 11-14 Age Group Students in Terms of Gender. International Journal of Social Science Research, 5(2), 1-9.

Aygün, Ö. (2004). Comparison of Pre-Training and Motoric Performance in Mentally Handicapped. Unpublished Master's Thesis, Sakarya University, Sakarya.

Bozkurt, M. T., Demir, T. G. ve Dursun, M. (2019). Examination of Sports Participation Motivations of Physically, Hearing and Visually Impaired Athletes, Volume: 12 Numbers: 6, 721-728.

Büyüköztürk, S., Kılıç Çakmak, E., Akgün, Ö. E., Karadeniz, S., \& Demirel, F. (2012). Scientific Research Methods (18th Edition). Ankara: Pegem Academy Publishing.

Büyüköztürk, Ş., Çakmak, E. K., Akgün, Ö. E., Karadeniz, Ş., \& Demirel, F. (2017). Scientific Research Methods. Pegem Citation Index, 1-360.

Coşkuntürk, O. (1988). Effects of Self-Confidence, Determination and Success Impulse on Sportive Performance and Development from Personality Traits, Master Thesis, Gazi. University. Social Sciences Institute, Department of Physical Education and Sports, Ankara. 
Cüceloğlu, D. (2006). Human and Behavior, 15th Edition, Istanbul: Remzi Bookstore.

Deimann, M. Ve Bastiaens, T. (2010). The Role of Volition İn Distance Education: An Exploration Of İts Capacities. International Review of Research İn Open and Distributed Learning, 11(1), 1-16.

Demir, G. T. and İlhan, El. (2019). Sports Participation Motivation: A Study on Visually Impaired Athletes. Gaziantep University Journal of Sports Sciences, 4 (1), 157-170. Determining the Reasons of Primary and Secondary School Students' Participation in Physical Activity: The Example of Nevşehir. Gaziantep University Journal of Social Sciences, 15(4), 1075-1085. DOI: 10.21547/Jss.265491.

Eren, E. (2004). Organizational Behavior and Management Psychology. Extended 8th Edition, İstanbul: Beta Publishing.

Eroğlu, S. (2007). Organizational Commitment and Motivation Levels of Secondary Education Institutions in Secondary Education Institutions. Master Thesis, Yeditepe University, Istanbul.

Frederic, G., Ve Ark. (1996). Motivation and Elite Performance: An Exploratory Investigation with Bulgarian Athletes, International Journal of Sport Psychology, 27, 173-182.

Funk, D. C. (2008). Consumer Behavior İn Sport and Events: Marketing Action, Oxford: Elsevier.

Genç, N. (2004). Management and Organization, Contemporary Systems and Approaches. Seçkin Publishing, Ankara.

Gülbahçe, Ö., Tozoğlu, E., Bayraktar, G., Dursun, M., ve Gülbahçe, A. (2018). The Analysis Of Relation Between Different Varıables And University Students 'motives For Participation in Sports. European Journal of Physical Education and Sport Science.

Güven, H., Fikret, S., \& Yusuf, C. (2000). Evaluation of Factors Affecting Efficiency in Sports Services. Gazi Physical Education and Sport Sciences First Congress Proceedings, Volume II, Ankara: Sim Matbaacılık, S; 183-188.

Huett, J. B., Moller, L., Young, J., Bray, M., Ve Huett, K. C. (2008). Supporting the Distant Student: The Effect Of ARCS-Based Strategies on Confidence and Performance. Quarterly Review of Distance Education, 9(2), 113-126.

Janna, L. C., \& Monika, S. (2008). Disabilities İn Kenya, With Implications for The Development of A New Hierarchical Model Of Constraints At The Societal Level. Joumat Of Leisure Lie Search, 40: 128-155.

Jokelova, A. (2013). ARCS Motivational Model: Theoretical Concepts and its Use in Online Courses. In 2013 IEEE 11th International Conference on Emerging Elearning Technologies And Applications (ICETA), 189-194.

Kaman, M. B., Gündüz, N., Ve Gevat, C. (2017). Examining Sports Participation Motivations of Tennis Athletes. SPORMETER, 15 (2), 65-72.

Karakaş, G., Kolayiş, İ. E., And Eskiler, E. (2015). Examination of Exercise Motivations of Women Participating in Swimming Exercise. Proceedings of The III Recreation Research Congress, Eskişehir, Turkey, 5-7 November. 
Karataş Ö, Yücel, A. S. Karademir, T. Karakaya, Y. E. (2011). Investigation of the Competence Level of Sports Facilities in the Spread of Sport in Malatya, Hacettepe J. of Sport Sciences 22 (4), 154-163.

Kazak, Z. (2004). Reliability and Validity Study of Turkish Motivation for Sport Motivation Scale-SGÖ-N. Hacettepe University Journal of Sports Sciences, 15 (4), 191-206.

Kızar, O., Savucu, Y., Yücel, A. S., Kargün, M. (2018). Investigation of Sports Facilities Adequacy Levels for People with Disabilities in Turkey. Turkish Studies Social Sciences Volume 13/26, Fall 2018, P. 829-848.

Kurkova P., Válková H., Scheetz N. (2011). Factors impacting participation of European elite deaf athletes in sport, Journal of Sports Sciences, 29:6, 607-618.

Mittler, P. (2008). Planning of 2040's; Everyone's Mission, Öz-Veri Magazine, 5: 12-15.

Polat, E., Doğan, B., Mutlu, F. (2018). An Investigation of Sport Participation Motives of The Individuals Doing Recreative Sports And Competitive Sports, International Journal Of Social Science Research, 7(2), 175-187.

Soyer, F., Can, Y., Güven, H., Hergüner, G., Bayansalduz, M. \& Tetik, B. (2010). Sporculardaki Başarı Motivasyonu İle Takım Birlikteliği Arasındaki İlişkinin İncelenmesi. Uluslararası İnsan Bilimleri Dergisi, Cilt.7, Sayı.1: 225-239.

Smith, R. (2008). Motivational Factors İn E-Learning. George Washington University. http://el-gor.at/elearn/medien/motivation.pdf.

Theodosiou, M. (2005). Motivational Climate, Achievement Goals and Undergraduate Students. Sport Science. Vol 19.No 5.

Tekkurşun Demir, G., \& Cicioğlu, H. İ. (2018). Fiziksel Aktiviteye Katılım Motivasyonu Ölçeği (FAKMÖ): Geçerlik ve güvenirlik çalışması. Journal of Human Sciences, 15(4), 2479-2492. doi:10.14687/jhs.v15i4.5585

Tekkurşun Demir, G., Yılmaz, A., Esentürk, O. K., Ve İlhan, E. L. (2016). Why Does My Child Swim Mechanism of Parent Guidance? Science, Movement and Health, 16(2), 442-448.

Tekkurşun, D. G., İlhan, E. L., Esentürk, O. K., \& Adnan, K. A. N. (2018). Sports participation motivation scale (ESSMÖ) in individuals with disabilities: validity and reliability study. SPORMETRE, 16 (1), 95-106.

Tekkurşun-Demir, G. \& İlhan, E. L. (2019). Motivation to participate in sports in athletes with disabilities. Ankara university Faculty of Educational Sciences Journal of Special Education, Early View. doi: 10.21565/private magazine.490063

Temel, V. (2018). The Motivation of Table Tennis and Wushu Athletes. Gazi Journal of Physical Education and Sports Sciences, 23 (3), 143-152.

Turan, F. A. (2010). The Role of Loneliness, Self-Esteem, Age, Gender and Romantic Relationship in Predicting University Students' Cognitive Distortions in Relations, Anadolu University Graduate School of Educational Sciences. Eskisehir.

Yalçın, İ., Turğut. M., Gacar, A., Çalık, F. (2017). Investigation of Sports Participation Motivations of Women Athletes Studying in School of Physical Education and 
Sports According to Some Variables, International Journal of Cultural and Social Studies. December: Volume 3 (Special Issue) e-ISSN: 2458-9381.

Yildırım, M. (2017). Determination of Factors Affecting Sports Participation Motivations of Athletes Fighting in University Teams (Example of Eskişehir Osmangazi University). Eskişehir Osmangazi University Journal of Social Sciences, 18 (1), 4151.

Yilmaz, E. (2007). The Role of Motivation in Student Success in English Lessons in Secondary Education: The Case of Bartin Province. Master Thesis, Karaelmas University, Zonguldak. 
Oktay Kızar, Gönül Tekkurşun Demir, Harun Genç

EXAMINATION OF THE EFFECT OF NATIONAL AND AMATEUR DISABLED ATHLETES' DISABILTY TYPES ON SPORTS PARTICIPATION MOTIVATION

Creative Commons licensing terms

Authors will retain the copyright of their published articles agreeing that a Creative Commons Attribution 4.0 International License (CC BY 4.0) terms will be applied to their work. Under the terms of this license, no permission is required from the author(s) or publisher for members of the community to copy, distribute, transmit or adapt the article content, providing a proper, prominent and unambiguous attribution to the authors in a manner that makes clear that the materials are being reused under permission of a Creative Commons License. Views, opinions and conclusions expressed in this research article are views, opinions and conclusions of the author(s). Open Access Publishing Group and European Journal of Physical Education and Sport Science shall not be responsible or answerable for any loss, damage or liability caused in relation to/arising out of conflict of interests, copyright violations and inappropriate or inaccurate use of any kind content related or integrated on the research work. All the published works are meeting the Open Access Publishing requirements and can be freely accessed, shared, modified, distributed and used in educational, commercial and non-commercial purposes under a Creative Commons attribution 4.0 International License (CC BY 4.0). 